\title{
Pengawasan Otoritas Jasa Keuangan terhadap Pelaku Usaha Pegadaian Illegal
}

\section{Supervision Of Financial Services Authority Against Illegal Powdership Business Actors}

\author{
Budiarto Sembiring ${ }^{1)}$, Isnaini ${ }^{1)} *$ \& Jelly Leviza ${ }^{2}$ )
}

\author{
1)Program Studi Magister Ilmu Hukum, Universitas Medan Area, Indonesia \\ 2) Program Studi Magister Ilmu Hukum, Universitas Sumatera Utara, Indonesia \\ Diterima: 05 Juli 2021; Direview: 31 Juli 2021; Disetujui: 03 Oktober 2021
}

*Coresponding Email: isnaini@staff.uma

\section{Abstrak}

Tulisan ini bertujuan untuk mengkaji dan menganalisis aturan hukum tentang pegadaian, pengawasan 0JK terhadap pelaku usaha pegadaian illegal pada OJK Kantor Regional 5 Sumatera Bagian Utara dan kendala yang dihadapi dalam pengawasan 0JK terhadap pelaku usaha pegadaian illegal pada OJK Kantor Regional 5 Sumatera Bagian Utara. Guna mendekati masalah ini dipergunakan teori sistem hukum. Data-data dikumpulkan melalui pedoman wawancara dan dianalisis secara kualitatif. Hasil dan pembahasan pada penelitian ini bahwa aturan hukum tentang pegadaian diatur dalam Undang-Undang Nomor 40 Tahun 2007 Tentang PerseroanTerbatas, Undang-Undang Nomor 17 Tahun 2012 Tentang Koperasi, Peraturan Otoritas Jasa Keuangan Nomor31/POJK.05/2016 Tentang Usaha Pegadaian OJK. Kajian ini menyimpulkan bahwa pengawasan yang dilakukan masih sebatas pada sosialisasi untuk menghimbau pelaku usaha agar melakukan pengurusan izin usaha, serta menghimbau kepada masyarakat umum agar tidak menggunakan jasa usaha pegadaian illegal. OJK tidak dapat memberikan sanksi kepada pelaku usaha gadai illegal, karena belum ada aturan hukum yang mengatur sanksi yang dapat diberikan kepada para pelaku usaha illegal. Adapun kendala yang dihadapi dalam pengawasan OJK terhadap pelaku usaha illegal adalah: belum ada aturan hukum mengenai sanksi yang dapat diberikan kepada para pelaku usaha pegadaian illegal, banyak pelaku usaha gadai tidak dapat memenuhi syarat permodalan yang ditetapkan oleh 0JK, kerjasama 0JK dengan SWI masih lemah karena adanya anggapan bahwa masalah pelaku usaha gadai illegal belum terlalu mendesak untuk diurusi sehingga terkesan diabaikan, rendahnya keperdulian masyarakat sehingga tetap menggunakan jasa usaha pegadaian illegal, serta sosialisasi yang kurang gencar tentang perizinan usaha pegadaian.

Kata Kunci : Pengawasan OJK; Pelaku Usaha; Pegadaian Illegal

\section{Abstract}

This paper aims to examine and analyze the legal rules regarding pawnshops, OJK supervision of illegal pawnshop business actors at OJK Regional Office 5 North Sumatra and the obstacles faced in OJK supervision of illegal pawnshop business actors at OJK Regional Office 5 North Sumatra. To approach this problem, the theory of the legal system is used. The data were collected through interview guidelines and analyzed qualitatively. This study concludes that the legal rules regarding pawnshops are regulated in Law Number 40 of 2007 concerning Limited Liability Companies, Law Number 17 of 2012 concerning Cooperatives, Financial Services Authority Regulation Number 31/POJK.05/2016 concerning OJK's Pawnshop Business. OJK's supervision of illegal business actors in OJK Region 5 North Sumatra has not been carried out strictly, it even seems that the OJK has neglected it. The obstacles faced in OJK's supervision of illegal business actors are: there is no legal regulation regarding sanctions that can be given to illegal pawnshop business actors, many pawn business actors cannot meet the capital requirements set by OJK, OJK's cooperation with SWI is still weak because there is an assumption that the problem of illegal pawn business actors is not too urgent to be taken care of so that it seems to be ignored, the public's lack of concern so that they continue to use illegal pawnshop business services, as well as less intensive socialization about pawn business licensing. Keywords: OJK Supervision; Business Actors; Illegal Pawnshops

How to Cite: Sembiring, B., Isnaini., \& Leviza, J. (2021). Pengawasan Otoritas Jasa Keuangan Terhadap Pelaku Usaha Pegadaian Illegal (Studi Pada Otoritas Jasa Keuangan Kantor Regional 5 Sumatera Bagian Utara). Journal of Education, Humaniora and Social Sciences (JEHSS). 4 (2): 1129-1135 赵 http://mahesainstitute.web.id/ojs2/index.php/jehss @ mahesainstitut@gmail.com 1129 


\section{PENDAHULUAN}

Tingginya minat masyarakat terhadap pegadaian menyebabkan usaha pegadaian atau rumah gadai semakin banyak bermunculan di berbagai kota dan daerah, termasuk juga di Kota Medan dan di wilayah lain di Provinsi Sumatera Utara. Bisnis pegadaian tidak lagi didominasi oleh Perum Pegadaian, tetapi juga telah diramaikan oleh banyak perusahaan pegadaian swasta. Berbagai jenis barang dapat digadaikan, seperti HP, laptop, emas, kamera, sepeda motor, mobil serta semua barang-barang yang dianggap memiliki nilai ekonomis jangka panjang, sehingga dapat dilelang jika terjadi wanprestasi pembayaran utang oleh debitur (Akhbar, Dkk, 2019).

Sebenarnya dengan adanya pegadaian swasta saat ini masyarakat lebih terbantu dalam usaha memenuhi kebutuhannya terhadap dana dengan cara yang relative singkat dan sederhana. Tetapi menjamurnya usaha gadai swasta juga dapat membawa dampak negatif terhadap nasabah. Terdapat risiko yang cukup potensial bagi nasabah terutama jika usaha gadai tidak mendapat izin dari Otoritas Jasa Keuangan (OJK) sehingga dianggap illegal.

Usaha gadai illegal tanpa izin usaha dari OJK berpotensi menyebabkan usaha gadai melakukan pelanggaran terhadap hak-hak nasabah, karena dalam hal ini kepentingan nasabah tidak mendapat perlindungan yang memadai, jika ternyata suatu saat terjadi masalah hukum atas barang yang digadaikan. OJK telah mengidentifikasi sekitar 460 perusahaan gadai yang beroperasi secara illegal di Indonesia. Omzet mereka mencapai Rp 600 miliar dengan jumlah nasabah sekitar 700 ribu orang. Pengelola bisnis ini kebanyakan berbentuk koperasi dan cukup banyak pula perseroan terbatas. Meski omzetnya hanya sekitar lima persen dari pangsa pasar pegadaian di Indonesia, kalau praktik ini dibiarkan berlarut-larut dan terjadi penyelewengan, jelas sejumlah besar masyarakat akan dirugikan (Ginting \& Muazzul, 2018).

Beberapa perlakuan perusahaan gadai swasta yang mungkin dapat merugikan nasabah adalah: Menggunakan atau memanfaatkan barang gadai selama barang gadai dalam penguasaan perusahaan gadai, atau tidak melakukan pemeliharaan dan penyimpanan yang memadai sehingga menyebabkan kerusakan terhadap barang gadai. Permasalahan lain yang juga sering terjadi adalah perusahaan gadai dapat berlaku sewenang-wenang dengan melakukan lelang terhadap barang gadai tanpa sepengetahuan dari nasabah, padahal sesuai aturan hukum bahwa proses lelang terhadap barang gadai hanya dapat dilakukan oleh perusahaan gadai setelah terlebih dahulu memberitahukannya kepada nasabah yang dianggap wanprestasi. Jika nasabah menggadaikan barang pada pegadaian swasta illegal, maka nasabah tersebut tidak dapat memperoleh perlindungan hukum yang memadai jika hak-haknya dilanggar oleh perusahaan gadai. Disamping itu, perusahaan gadai illegal yang tidak memiliki izin dari OJK juga cenderung tidak sehat, baik secara finansial maupun secara prosedur sehingga sangat berpotensi menyebabkan kerugian bagi nasabah (Hasmayni, 2016).

OJK (Otoritas Jasa Keuangan) merupakan lembaga pengawas industri jasa keuangan. Tugastugasnya terdapat dalam Pasal 8 huruf i Undang-Undang No. 21 Tahun 2011 Tentang Otoritas Jasa Keuangan yaitu menetapkan peraturan mengenai tata cara pengenaan sanksi sesuai dengan ketentuan peraturan perundang-undangan di sektor jasa keuangan. Berdasarkan Pasal 9 huruf $g$ dan huruf h Undang-Undang No. 21 Tahun 2011 Tentang Otoritas Jasa Keuangan dapat memberikan dan mencabut izin usaha; izin orang perseorangan; efektifnya pernyataan pendaftaran; surat tanda terdaftar; persetujuan melakukan kegiatan usaha; pengesahan; penetapan atau persetujuan pembubaran; dan penetapan lain sebagaimana dimaksud dalam peraturan Perundang-Undangan di sektor jasa keuangan.

Perlindungan hukum dapat diartikan sebagai pemberian jaminan dan kepastian bahwa seseorang akan mendapatkan apa yang menjadi hak dan kewajibannya atau perlindungan terhadap kepentingannya, sehingga yang bersangkutkan merasa aman. Perlindungan hukum diberikan dengan tujuan untuk mencegah terjadinya sengketa. Perlindungan hukum juga diberikan kepada setiap orang sebagai wadah penanggulangan untuk menimbulkan rasa aman dan meminimalisir sengketa yang menimbulkan kerugian baik dari pihak pelaku usaha maupun nasabah. Nasabah mempunyai hak untuk mendapatkan informasi yang benar, jelas dan jujur atas legalitas tentang usaha pergadaian tersebut, dengan informasi yang utuh dari pelaku usaha pergadaian itulah nasabah dapat menentukan pilihannya dengan benar terhadap produk yang aman sebagai inti kegiatan usaha pergadaian yaitu penyaluran dana pinjaman, jasa penitipan 
barang berharga dan memberikan jasa taksir terhadap kualitas barang jaminan (Siallagan \& Siregar, 2017).

Oleh karena itu OJK telah membuat aturan hukum agar perusahaan gadai swasta yang semakin banyak menjamur di tengah masyarakat dilengkapi dengan legalitas izin usaha. OJK sebagai pihak yang berwewenang melakukan pengawasan terhadap transaksi jasa keuangan di Indonesia telah mengeluarkan peraturan No. 31/P0JK.05/2016 tentang Usaha Pegadaian. Peraturan tersebut mengharuskan perusahaan pegadaian swasta memiliki izin usaha, serta mengatur penyelenggaraan usaha gadai swasta, dengan tujuan untuk menjamin perlindungan hukum bagi nasabah yang memanfaatkan jasa gadai swasta.

Peraturan tersebut meninsyaratkan pelaku usaha swasta diwajibkan mendapatkan izin. Selain itu, bisnis ini juga dibatasi hanya untuk pelaku nonkorporasi. Hingga Mei 2018, OJK mencatat ada 24 perusahaan gadai yang telah terdaftar dan berizin. Perusahaan yang terdaftar terdiri dari KSP Mandiri Sejahtera Abadi di Semarang, KSU Dana Usaha di Semarang, PT.Mitra Kita di Semarang, UD Ijab di Semarang, PT.Mas Agung Sejahtera di Jakarta, PT.Surya Pilar Kencana di Jakarta, PT.Svaraputra Penjuru Vijaya di Tangerang, PT.Pusat Gadai Indonesia di Jakarta, PT.Persada Arihta Mandiri di Medan, Solusi Gadai di Jakarta, CV.Soverino Eka Sakti di Semarang, CV.Prima Perkasa di Semarang, Gadai Murah Jogja di Yogyakarta, dan PT.Awi Gadai Jogja di Yogyakarta. Sementara perusahaan yang berizin yakni PT.Pegadaian (Persero) di Jakarta, PT.HBD Gadai Nusantara di Jakarta, PT.Gadai Pinjam Indonesia di Jakarta, PT.Sarana Gadai Prioritas di Jakarta, PT.Mitra Gadai Sejahtera Kepri di Kepulauan Riau, PT.Sili Gadai Nusantara di Semarang, PT.Jawa Barat Gadai Sejati di Bekasi, PT.Pergadaian Dana Sentosa di Yogyakarta, PT.Sahabat Gadai Sejati di Bandung, dan PT.Jasa Gadai Syariah di Bekasi (Sitorus, Dkk, 2020).

Tetapi sejak dikeluarkannya peraturan OJK tersebut hingga saat ini masih terdapat banyak perusahaan gadai illegal karena tidak memiliki izin usaha. Hal ini dapat dilihat dari banyaknya usaha gadai yang tidak dilengkapi dengan logo OJK. Berdasarkan data dari Satgas Waspada Investasi (SWI) menunjukkan, ada sekitar 50 usaha pegadaian swasta ilegal yang dilakukan tanpa izin dari OJK. Hal ini disampaikan oleh Ketua SWI, Tongam L Tobing yang mengatakan, izin yang dimaksud adalah izin yang sesuai dengan Peraturan Otoritas Jasa Keuangan (OJK) Nomor: 31/POJK.05/2016 tentang Usaha Pergadaian (POJK). Jumlah pelaku usaha gadai illegal sampai bulan September 2020 di Sumatera Utara, Medan ada sebanyak 18 pelaku usaha.

Berdasarkan uraian di atas penelitian ini penting karena hal-hal sebagai berikut: Diterbitkannya peraturan OJK tidak menjamin semua usaha jasa gadai mematuhi ketentuan legalitas perizinan usaha, terutama bagi usaha gadai yang berada di toko pinggir jalan. Banyak usaha gadai illegal tetap dapat beroperasi, baik yang telah lama berdiri maupun yang masih baru berdiri, sehingga sangat berpotensi merugikan nasabah, karena banyak diantara usaha tersebut tidak memiliki kelayakan sebagai usaha gadai. OJK sebagai instansi yang berwewenang melakukan pengawasan terhadap perusahaan jasa keuangan masih kurang ketat tentang aturan perizinan yang diterbitkan OJK, karena OJK justru cenderung melakukan pembiaran tanpa adanya upaya yang tegas untuk melakukan penertiban terhadap usaha gadai illegal.

\section{METODE PENELITIAN}

Spesifikasi penelitian yang dipergunakan dalam penulisan artikel ini adalah metode penelitian yuridis normatif bersifat deskriptif analisis, yaitu penelitian yang dilakukan dengan cara meneliti bahan pustaka (data sekunder) atau penelitian hukum perpustakaan. Penelitian hukum normatif merupakan suatu prosedur penelitian ilmiah untuk menemukan kebenaran berdasarkan logika keilmuan hukum dari sisi normatifnya. Penelitian hukum normatif atau doktriner yang diajukan dalam kajian ini adalah penelitian terhadap asas-asas hukum dan sinkronisasi hukum.

Penelitian ini menggunakan bahan yang diperoleh dari hasil penelitian kepustakaan, dari penelitian kepustakaan dikumpulkan data sekunder yang meliputi bahan hukum primer, bahan 
hukum sekunder dan bahan hukum tersier. Penelitian normatif, data yang diperlukan adalah data sekunder. Data sekunder tersebut mempunyai ruang lingkup yang sangat luas, sehingga meliputi surat-surat pribadi, buku-buku harian, sampai pada dokumen-dokumen resmi yang dikeluarkan oleh pemertintah.

Alat pengumpulan data menggunakan studi dokumen dan pedoman wawancara. Data yang diperoleh melalui penelitian kepustakaan maupun data yang diperoleh melalui penelitian lapangan akan dianalisis secara kualitatif. Analisis kualitatif yaitu analisis data dengan mengelompokkan dan menyelidiki data yang diperoleh dari penelitian lapangan menurut kualitas kebenarannya, kemudian dihubungkan dengan teori-teori yang diperoleh dari studi kepustakaan, sehingga diperoleh jawaban dari permasalahan yang diajukan.

\section{HASIL DAN PEMBAHASAN}

\section{Aturan hukum tentang pegadaian}

Gadai diperjanjikan dengan maksud untuk memberikan jaminan atas suatu kewajiban prestasi tertentu, yang pada umumnya tidak selalu merupakan perjanjian utang piutang dan karenanya dapat diketahui bahwa perjanjian gadai mengabdi kepada perjanjian pokoknya atau perjanjian gadai tersebut merupakan perjanjian yang bersifat accessoir. Pada prinsipnya (barang) gadai dapat dipakai untuk menjamin setiap kewajiban prestasi tertentu.

Gadai diatur dalam Bab XX Buku II Kitab Undang-undang Hukum Perdata Pasal 1150 Kitab Undang-undang Hukum Perdata sampai dengan Pasal 1160 Kitab Undang-undang Hukum Perdata. Karena benda-benda yang digadaikan menyangkut benda-benda bergerak, maka ketentuan pasalpasal tersebut dinyatakan masih berlaku.

Apa yang dimaksud dengan gadai dalam Pasal 1150 Kitab Undang-undang Hukum Perdata merumuskan sebagai berikut:

Gadai adalah suatu hak yang diperoleh seorang berpiutang atas suatu barang bergerak, yang diserahkan kepadanya oleh seorang berutang atau oleh seorang lain atas namanya, dan yang memberikan kekuasaan kepada si berpiutang itu untuk mengambil pelunasan dari barang tersebut secara didahulukan daripada orang-orang berpiutang lainnya, dengan kekecualian biaya untuk melelang barang tersebut dan biaya yang telah dikeluarkan untuk menyelamatkan setelah barang itu digadaikan, biaya-biaya mana harus didahulukan.

Dasar hukum gadai dapat dilihat pada peraturan perundangan-undangan berikut ini:

1. Pasal 1150 KUH Perdata sampai dengan Pasal 1160 Buku II KUH Perdata;

2. Artikel 1196vv, titel 19 Buku III NBW;

3. Peraturan Pemerintah Nomor 7 Tahun 1969 tentang Perusahaan Jawatan Pegadaian;

4. Peraturan Pemerintah Nomor 10 Tahun 1970 tentang Perubahan Peraturan Pemerintah Nomor 7 Tahun 1969 tentang Perusahaan Jawatan Pegadaian;

5. Peraturan Pemerintah Nomor 103 Tahun 2000 tentang Perusahaan Umum (Perum) Pegadaian;

6. Peraturan Pemerintah No 51 tahun 2011 tentang Perusahaan Perseroan (Persero).

Perseroan Terbatas (selanjutnya disebut sebagai PT) adalah badan hukum yang merupakan persekutuan modal, didirikan berdasarkan perjanjian, melakukan kegiatan usaha dengan modal dasar yang seluruhnya terbagi dalam saham, dan memenuhi persyaratan yang ditetapkan dalam Undang-Undang ini peraturan pelaksanaannya.

Berdasarkan pasal 1 ayat 1 UU OJK disebutkan bahwa Otoritas Jasa Keuangan adalah lembaga yang independen dan bebas dari campur tangan pihak lain, yang mempunyai fungsi, tugas dan wewenang pengaturan, pengawasan, pemeriksaan dan penyidikan sebagaimana dimaksud dalam Undang-Undang ini. Independensi yang dimaksud di atas bukan berarti OJK bebas dalam menjalankan pengaturan dan pengawasan sesuai yang mereka inginkan. Dalam hal ini, independensi yang dimaksud artinya OJK dapat mempergunakan instrumen yang dimilikinya untuk mencapai tujuan sebagaimana telah ditetapkan oleh sistem politik tanpa adanya campur tangan dari pihak luar OJK (Tambunan, Dkk, 2019). 


\section{Pengawasan 0JK terhadap pelaku usaha pegadaian illegal pada Otoritas Jasa Keuangan Kantor Regional 5 Sumatera Bagian Utara.}

Upaya pengawasan yang dapat dilakukan oleh OJK terhadap pelaku usaha illegal adalah dengan melakukan sosialisasi terhadap para pelaku usaha. Sosialisasi tersebut dimaksudkan agar pelaku usaha secara sadar memahami pentingnya perizinan dari OJK, agar keberadaan usaha gadai yang bersangkutan menjadi sah di tengah-tengah masyarakat, serta menyadari syarat-syarat apa yang seharusnya dipenuhi sebagai pelaku usaha gadai (Zulyadi, 2020).

Sosialisasi oleh 0JK juga dilakukan keapda masyarakat umum, agar masyarakat mengetahui bahwa setiap pelaku usaha gadai harus memiliki izin OJK. Adapun tujuan dari sosialisasi adalah agar masyarakat menyadari risiko yang mungkin timbul dari penggunaan jasa gadai illegal, sehingga sedapat mungkin dapat menghindari peminjaman dana dari usaha illegal tersebut.

Sampai saat ini upaya sosialisasi yang dilakukan oleh 0JK menghimbau masyarkat untuk tidak menggunakan jasa gadai tak berizin belum belum berhasil. Masyarakat cenderung mengabaikan peringatan yang diberikan oleh OJK sehingga usaha gadai illegal tetap eksis dengan operasional usahanya. Hal ini mungkin disebabkan masyarakat tidak terlalu takut karena nilai gadaian dan nilai kredit relatif kecil, padahal kondisi ini tentu semakin mendorong munculnya usaha gadai illegal.

Wewenang OJK dalam menindak pelaku usaha gadai illegal adalah sangat terbatas, karena OJK tidak dapat memberi sanksi administrasi ataupun bentuk sanksi lainnya.OJK hanya berwenang memberi sanksi kepada pelaku usaha legal yang melakukan pelanggaran hukum. Hal ini karena tidak aturan hukum yang mengatur sanksi bagi para pelaku usaha illegal, dimana pihak yang paling berwenang memberikan sanksi adalah Satgas Waspada Investasi (SWI).

\section{Kendala yang dihadapi dalam pengawasan 0JK terhadap pelaku usaha pegadaian illegal pada Otoritas Jasa Keuangan Kantor Regional 5 Sumatera Bagian Utara}

Belum ada sanksi bagi pelaku usaha pegadaian illegal. Gadai swata yang belum mendapat izin atau illegal tidak dapat diberi sanksi karena memang dasar hukumnya tidak ada. Dengan tidak adanya dasar hukum untuk mmberikan sanksi maka pengawasan secara ketat juga tidak dapat dilakukan.

Sanksi yang paling kuat adalah sanksi yang didasarkan pada UU, dimana UU secara hukum tata negara dapat memberikan sanksi pidana atas perbuatan melawan hukum. Tidak adanya sanksi pidana yang diatur oleh UU menyebabkan OJK menjadi terlalu lemah.

Wewenang pengawasan yang menjadi otoritas 0JK menjadi sangat lemah karena tidak adanya dasar hukum atau payung hukum berupa UU. Jika OJK hanya dapat membuat himbauan tanpa dapat mengancamkan sanksi khususnya sanksi pidana, maka himbauan yang diberikan oleh OJK akan percuma karena tidak memberi efek kepatuhan dari masyarakat atau pelaku usaha illegal.

Kendala permodalan. Pelaku usaha gadai lebih memilih untuk tidak mengurus izn usaha dari OJK karena persyaratan modalnya relatif besar, yaitu mencapai Rp. 500.000.000.Padahal sebenarnya usaha gadai sangat mudah didirikan hanya dengan bermodalkan puluhan juga rupiah. Disamping itu, banyak pelaku usaha gadai memang tidak mampu memenuhi peryaratan modal.

Persyaratan permodalan yang relatif besar, maka sangat banyak pelaku usaha gadai, baik yang sudah berdiri maupun yang akan berdiri memilih untuk menghindari pengurusan izin usaha. Padahal konsumennya tetaplah ada walaupun tidak mencantumkan logo OJK. Ketidakmampuan pemenuhan modal karena banyak darinya adalah usaha kecil.

Usaha gadai yang didirikan oleh masyarakat tentu adalah usaha dengan modal kecil dan tidak memungkinkan mampu menyediakan modal hingga ratusan juta rupiah sebagaimana dipersyaratkan oleh OJK.Terdapat juga kemungkinan bahwa usaha gadai yang dikelola adalah usaha sampingan sebagaimana banyak dilakukan usaha keluarga selama ini.

Kerjasama OJK dengan SWI Masih Lemah. SWI yang memiliki wewenang yang lebih tinggi dalam pengawasan terhadap transaksi investasi memiliki kewenangan untuk melakukan tindakan 
paksa, tetapi SWI bukan bagian dari OJK sehingga tidak dapat secara leluasa untuk menggunakannya dalam pengawasan terhadap pelaku usaha gadai illegal.

Tidak ada usaha yang serius dari masing-masing pihak untuk menegakkan izin usaha bagi pelaku usaha illegal dengan alasan bahwa masalah tersebut masih terlalu kecil untuk perlu diurusi oleh SWI. Mengurusi usaha gadai illegal dianggap sebagai membuang waktu dan energy karena masih banyak urusan investasi lainnya yang lebih mendesak untuk diurusi.

Rendahnya keperdulian masyarakat. Pengetahuan atau kesadaran masyarakat mengenai keharusan adanya izin usaha bagi pelaku usaha gadai masih tergolong kurang. Masyarakat tidak terlalu perduli terhadap masalah perizinan usaha gadai sehingga tidak menjadi salah satu perhatian dalam memilih usaha gadai. Padahal sepanjang masyarakat masih mau menggunakan jasa gadai, maka usaha tersebut akan tetap berjalan.

Tidak adanya kesadaran masyarakat bahwa mendirikan usaha gadai tanpa izin 0JK adalah perbuatan melawan hukum, maka masyarakat masih tetap akan menggunakan jasa gadai illegal, dan pelaku usaha tetap akan mendapat keuntungan dari hasil usahanya. Hal ini tentu berdampak negative terhadap upaya OJK menertibkan usaha gadai illegal.

Sosialisasi Kurang Gencar. Peraturan OJK tentang perlunya perizinan usaha bagi pelaku usaha gadai masih tergolong kurang gencar, sehingga terdapat kemungkinan masih banyak pelaku usaha dan masyarakat umum yang tidak memahami atau tidak menyadari adanya peraturan hukum tersebut. Hal ini juga menyebabkan banyak pelaku usaha illegal yang tidak memahami kewajiban usahanya.

Kurangnya sosialisasi maka terdapat banyak pelaku usaha gadai illegal yang tidak menyadari kewajibannya dalam mendirikan usaha gadai, yang berarti juga tidak menyadari bahwa usaha yang didirikanbnya telah melawan hukum.

\section{SIMPULAN}

Berdasarkan pembahasan dan hasil peneitian dari bab - bab sebelumnya, maka penulis akan menarik kesimpulan sebagai berikut: aturan hukum tentang pegadaian diatur dalam UndangUndang Nomor 40 Tahun 2007 Tentang PerseroanTerbatas, Undang-Undang Nomor 17 Tahun 2012 Tentang Koperasi, Peraturan Otoritas Jasa Keuangan Nomor31/POJK.05/2016 Tentang Usaha Pegadaian OJK. Pengawasan OJK terhadap pelaku usaha illegal pada OJK Region 5 Sumatera Bagian Utara belum dilakukan secara ketat, bahkan terkesan OJK melakukan pembiaran. Pengawasan yang dilakukan masih sebatas pada sosialisasi untuk menghimbau pelaku usaha agar melakukan pengurusan izin usaha, serta menghimbau kepada masyarakat umum agar tidak menggunakan jasa usaha pegadaian illegal. OJK tidak dapat memberikan sanksi kepada pelaku usaha gadai illegal, karena belum ada aturan hukum yang mengatur sanksi yang dapat diberikan kepada para pelaku usaha illegal. Adapun kendala yang dihadapi dalam pengawasan OJK terhadap pelaku usaha illegal adalah: belum ada aturan hukum mengenai sanksi yang dapat diberikan kepada para pelaku usaha pegadaian illegal, banyak pelaku usaha gadai tidak dapat memenuhi syarat permodalan yang ditetapkan oleh OJK, kerjasama OJK dengan SWI masih lemah karena adanya anggapan bahwa masalah pelaku usaha gadai illegal belum terlalu mendesak untuk diurusi sehingga terkesan diabaikan, rendahnya keperdulian masyarakat sehingga tetap menggunakan jasa usaha pegadaian illegal, serta sosialisasi yang kurang gencar tentang perizinan usaha pegadaian.

\section{DAFTAR PUSTAKA}

Akhbar, A.T.F, Maswandi \& Kartika A. (2019). Perlindungan Hukum Bagi Anak Dalam Tindak Pidana Pencurian Dengan Kekerasan Yang Mengakibatkan Matinya Korban (Studi Putusan No. 37/Pid.SusAnak/2017/PN. Mdn). JUNCTO, 1(2) 2019: 183-192,

Ginting, H. \& Muazzul. (2018). Peranan Kepolisian dalam Penerapan Restorative Justice terhadap Pelaku Tindak Pidana Pengeroyokan yang Dilakukan oleh Anak dan Orang Dewasa, Jurnal Ilmiah Penegakan Hukum, 5 (2): 32-40.

Hasmayni, B. (2016). Perilaku Agresif pada Anggota Geng Motor Ditinjau dari Tingkat Usia dan Suku di Kota Medan, Jurnal Pendidikan Ilmu-Ilmu Sosial, 8(2).

https://kolom.tempo.co/read/1091980/tindak-tegas-pegadaian-ilegal/full\&view=ok\#, diakses pada tanggal 2 November 2020. 
https://portalsurabaya.pikiran-rakyat.com/ekbis, diakses pada tanggal 2 November 2020.

Raka, I.G.G., (2012), Pengantar Pengetahuan Koperasi, Departemen Koperasi, Jakarta.

Siallangan, A.F, \& Siregar, T. (2017). Peranan Kantor Pengawasan Dan Pelayanan Bea Dan Cukai Belawan Dalam Penanggulangan Penyelundupan Satwa Dilindungi Jurnal Ilmiah Penegakan Hukum, 4 (1) 2017: 1-7

Sitorus, J., Zulyadi, R. \& Trisna, W. (2020). Perlindungan Hukum Terhadap Korban Tindak Pidana Pencurian Ditinjau Dari Kajian Victimlogi (Studi Putusan No : 20/Pid.B/2017/PN. Mdn). JUNCTO, 2(1) 2020: 41-50

SudutHukum.com, Pengertian Sanksi Administrasi, Dalam https://www.suduthukum.com/pengertiansanksi-administrasi.html, Diakses tanggal 10 Januari 2021.

Tambunan, R, Suhatrizal \& Siregar, T. (2019). Penegakan Hukum Terhadap Tindak Pidana Kepabean Penyeludupan Pakaian Bekas (Putusan No. 237/Pid.B/2016/PN. Tjb). JUNCTO, 1(2) 2019: 158-165,

Zulyadi, R. (2020). Perlindungan Hukum Terhadap Anak Sebagai Korban Perdagangan Manusia. Medan: C.V Pustaka Prima.

Perundang-undangan:

Kitab Undang-Undang Hukum Perdata (KUHPerdata)

Undang-Undang Nomor 40 Tahun 2007 tentang Perseroan Terbatas.

Instruksi Presiden RI Nomor 15 Tahun 1983 tentang Pedoman Pelaksanaan Pengawasan.

Peraturan OJK No. 31/POJK.05/2016 tentang Usaha Pegadaian.

Peraturan Menteri Hukum dan HAM RI Nomor: M. HH-03.AH.01.01Tahun 2009 tentang Daftar PT. 